Rev. Manfred Hauke

Theological Faculty of Lugano

iD 0000-0003-2087-0591

DOI: $10.15290 /$ rtk.2019.18.02

\title{
The Second Vatican Council's Doctrine on Mary and St. Pope John Paul II's Interpretation of It ${ }^{1}$
}

This article traces the origin and content of the Dogmatic Constitution on the Church: Lumen Gentium's chapter on Mary, which served as the focal point of the Second Vatican Council's doctrine on the Mother of God in the mystery of Christ and the Church. The article proceeds to describe the Archbishop of Cracow Karol Wojtyla's participation in conciliar discussions on Mary and then focuses on how Pope John Paul Il embraced conciliar Mariology and reflected it in his teachings. What St. Pope John Paul II wrote about Mary goes beyond Vatican II's Mariological teaching and includes Mary's mediation, consecration to Mary, and Her role as the "Spouse of the Holy Spirit." Pope Saint John Paul II offers a valuable paradigm for interpreting the Second Vatican Council.

Key words: Mariology, John Paul II, Lumen Gentium, Church, Blessed Virgin Mary, Mother of God, Second Vatican Council.

\section{Introduction}

The ancient Church called the Mother of God the "Scepter of Orthodox Faith," meaning that we perceive true faith and the importance of Jesus Christ in the Virgin Mary. ${ }^{2}$ While leading the Church on earth as Pope Benedict XVI (2005-2013), Joseph Ratzinger recalled a title

\footnotetext{
$1 \quad$ An earlier version of this article was published in German. See: M. Hauke, Die marianischen Aussagen des Zweiten Vatikanischen Konzils und ihre Interpretation durch Johannes Paul II, in Sedes Sapientiae. Marianisches Jahrbuch 16 (1/2012), pgs. 58-88.

2 Cf. Cyril of Alexandria, Sermo 4 (PG 77, 992-996) (Sermon at the Council of Ephesus, 431).
} 
Dogmatic Theology

used for Mary in the liturgy: "Conqueror of all Heresies." Mary plays a decisive role in the revitalization of the Catholic faith in every place that experiences a decline in the life of faith.

It seems very apropos to consider the Marian doctrine of the Second Vatican Council and St. Pope John Paul II's interpretation of it. Since distorted interpretations and presentations of this Council have contributed to the crisis within the Church, this study also touches on other Marian doctrines outside of those discussed by Vatican II. It is important to consider the doctrines that arose from Vatican II in light of the Tradition on which they are based and the Magisterium of the Church's authentic interpretations. During the Year of Faith (20122013), Pope Benedict XVI commemorated not only Vatican II, but also the 20th anniversary of the publication of the Catechism of the Catholic Church (CCC). The CCC contains a correct interpretation of Vatican II and connects the conciliar documents with the entire doctrine of the Church. John Paul II offers to Mariology what the CCC offers to the whole doctrine of the faith: a "hermeneutic of reform" that avoids any "hermeneutic of rupture," maintains continuity with the past, and contributes to further development of doctrine. Archbishop of Cracow Karol Wojtyla actively participated in conciliar discussions, including the sessions on Marian doctrine. As the Successor of St. Peter he had an important role in authentically interpreting and developing the doctrines of Vatican II.

The central document of Vatican II that is linked in many ways to the other conciliar documents is certainly the Dogmatic Constitution on the Church: Lumen Gentium. ${ }^{4}$ The Second Vatican Council's contribution to doctrine on the Church is so important that, to some degree, it can be called the "Council of the Church on the Church." Mary makes up part of the mystery of the Church: She is not only a "type" or "figure" of the Church, but also "Mother" of all of the members of

$3 \quad$ Cf. J. Ratzinger, The Ratzinger Report, San Francisco 1985, pg. 105.

4 See for instance G. Baraúna (ed.), “DeEcclesia,” Beiträge zur Konstitution, Über die Kirche“ des Zweiten Vatikanischen Konzils, 2 vols., Frankfurt 1966 (French edition: L'Eglise de Vatican II, 3 vols., Paris 1966-67); G. Philips, La Chiesa e il suo mistero nel Concilio Vaticano II. Storia, testo e commento della Costituzione "Lumen gentium," Milano 1975; (French original reprinted in 1993: L'Église et son mystère, Paris 1967); A. Anton, El misterio de la Iglesia. Evolución historica de las ideas eclesiologicas II, Madrid-Toledo 1987, pgs. 833-951; P. Hünermann, Theologischer Kommentarzur dogmatischen Konstitution über die Kirche Lumen gentium, in Idem - B.J. Hilberath (eds.), Herders Theologischer Kommentar zum Zweiten Vatikanischen Konzil II, Freiburg i.Br. 2004, pgs. 263-563.

5 This expression comes from K. Rahner, Das neue Bild der Kirche, in Geist und Leben 39 (1966) 4-24 (4); cf. Anton (1987) 841. 
the Mystical Body of Christ. The eighth chapter of Lumen Gentium is entitled "The Blessed Virgin Mary, Mother of God in the Mystery of Christ and the Church" and dedicated to the Mother of God. In Pope Dogmatic Theology Paul VI's address of November 21, 1964 to solemnly announce Lumen Gentium, Pope Paul VI called the Marian chapter the "culmination" (fastigium) of the document: the most profound center of the Church is its relationship with Christ, which cannot be separated from the Mother of the Word who became Man. ${ }^{6}$ Chapter VIII, which is longer than any other chapter in Lumen Gentium, crowns the most important document of Vatican II. Lumen Gentium discusses various topics, including, for instance, the collegiality of bishops and ecumenism; yet, no other part of the document has provoked so many commentaries than the chapter on Mary. ${ }^{7}$

The importance of Mariology to the Council corresponds in some way to the significant role that it played in John Paul II's teaching. This can be observed even in his papal coat of arms, which bears the

Acta Synodalia Sacrosancti Concilii Oecumenici Vaticani II, vol. III/8, 915 (= AAS 56, 1964, 1014).

Cf. for instance: R. Laurentin, La Madonna del Vaticano II, Bergamo 1965 (French original: La Vierge au Concile, Paris 1965); G. Besutti, Lo schema mariano del Vaticano II. Documentazione e note di cronaca, Roma 1966; C. Balić, "El capitolo VIII de la constitución 'Lumen gentium' comparado con el primer esquema de la Virgen Madre de la Iglesia," in Estudios Marianos 27 (1966), pgs. 135-183; Philips (1975) 511-585; G. Söll, Mariologie (HDG III,4), Freiburg i.Br. 1978, 238-240; L. Scheffczyk, Vaticanum II, in Marienlexikon 6(1994), pgs.567-571; S.M. Perrella, I "vota" e $i$ "consilia" dei vescovi italiani sulla mariologia e sulla corredenzione nella fasi antipreparatoria del Concilio Vaticano II, Roma 1994; Idem, La Madre di Gesù nella coscienza ecclesiale contemporanea, Città del Vaticano 2005, pgs. 1-140; Idem, Concilio Vaticano II, in S. de Fiores etc. (eds.), Mariologia, Cinisello Balsamo 2009, 308-319; M. Hauke, Die trinitarischen Beziehungen Mariens als Urbild der Kirche auf dem Zweiten Vatikanischen Konzil, in Sedes Sapientiae. Mariologisches Jahrbuch 4 (2/2000), pgs. 78-114; Idem, Introduzione alla mariologia (Collana di Mariologia 2), Lugano-Varese 2008, pgs. 94-98 (Introduction to Mariology, Washington, DC 2019 - manuscript in preparation); M. O'Carroll, "Theotokos," A Theological Encyclopedia of the Blessed Virgin Mary, Eugene, OR 22000, pgs. 351-356 (with more titles in English); E.M. Toniolo, La Beata Vergine Maria nel Concilio Vaticano II. Cronistoria del capitolo VII della Costituzione dogmatica "Lumen gentium" e sinossi di tutte le redazioni, Roma 2004; Idem (ed.), Maria nel Concilio. Approfondimenti e percorsi a 40 anni dalla "Lumen gentium," Roma 2005; S. De Fiores, Concilio Vaticano II, in Idem, Maria. Nuovissimo Dizionario I, Bologna 2006, 323-358; C. Antonelli, Il dibattito su Maria nel Concilio Vaticano II. Percorso redazionale sulla base di nuovi documenti di archivio, Padova 2009; A. Dittrich, Mater Ecclesiae. Geschichte und Bedeutung eines umstrittenen Marientitels, Würzburg 2009, pgs.573-686; A. Greco, "Madre dei viventi." La cooperazione salvifica di Maria nella "Lumen gentium:" una sfida per oggi (Collana di Mariologia 10), Lugano-Gavirate (Varese) 2011. 
Dogmatic Theology words "Totus tuus." In the course of his long pontificate, St. Pope John Paul II wrote on many topics. The American theologian Arthur Burton Calkins - the preeminent specialist on John Paul II's Mariology-writes in his anthology and commentary of Pope John Paul II's Marian writings: "I believe without the slightest doubt that the greatest heritage left to us by Pope John Paul II is his Marian magisterium."

To shed light on John Paul II's reception of the Second Vatican Council's teachings on Mary, I will first consider the origin and the content of the final chapter of Lumen Gentium. ${ }^{10}$ Then I will examine the Archbishop of Cracow's participation in the conciliar discussions on Marian doctrine. The main focus of this study is how St. Pope John Paul II received and then conveyed the Mariology of Vatican II in his papal teachings.

\section{The Origin and Content of Lumen Gentium's Chapter on Mary}

When considering what occurred over the long-term before Vatican II, it is important to mention Pope Pius XI's proclamation of the dogma of the Immaculate Conception in 1854. The magisterial pronouncement that Mary was conceived without original sin spurred a desire among bishops and theologians to define other Marian truths. At the First Vatican Council, which was interrupted by the war between Germany and France, many bishops expressed a desire to solemnly define the bodily Assumption of Mary into heaven. ${ }^{11}$ From the end of the $19^{\text {th }}$ century there was also an increasing desire to clarify and dogmatically proclaim

$8 \quad$ Cf. M. Hauke, Totus tuus. Theologische Grundlagen der Marienweihe, in A. von Brandenstein-Zeppelin etc. (eds.), Im Dienste der inkarnierten Wahrheit. Festschrift zum 25jährigen Pontifikat Seiner Heiligkeit Papst Johannes Pauls II, Weilheim-Bierbronnen 2003, pgs.127-148 (127-130).

A.B. Calkins, Introduzione, in Idem (ed.), Giovanni Paolo II, Totus tuus. Il magistero mariano di Giovanni Paolo II, Siena 2006, pgs. 9-37 (11): “Credo, senza la minima esitazione, che l'eredità più grande che Papa Giovanni Paolo II ci ha lasciato sia il suo magistero mariano."

10 While other Vatican II documents besides Lumen Gentium contain statements about Mary, the Constitution on the Church is the focal point of the Council's teaching on Mary. Perrella (2009) 317f, note 55 and Dittrich (2009) 673f include a list of these other documents: Sacrosanctum Concilium 103, Unitatis Redintegratio 14-15.20, Orientalium Ecclesiarum 30, Optatam Totius 8, Perfectae Caritatis 25, Nostra Aetate 3-4, Dei Verbum 8, Apostolicam Actuositatem 4, Presbyterorum Ordinis 18, Ad Gentes 4.42, Gaudium et Spes 22; Pope Paul VI's Address to Women. 
the Mother of God's universal mediation of grace. ${ }^{12}$ When Pope Pius XI announced his intention to continue Vatican I with Vatican II, he intended to consider the definition of two dogmatic truths: Mary's Assumption into heaven and Her role as Mediatrix of all Graces. ${ }^{13}$

When Pope Pius XII defined the dogma of the (bodily) Assumption of Mary into heaven in front of the entire Catholic episcopate on November 1, 1950, many of the bishops expected that the Council would dogmatically define Mary's role as Mediatrix. These expectations were manifested very clearly in the Roman Curia's response to the official inquiry of 1959 on the topics to be discussed during the Second Vatican Council. Until spring of 1960 , the bishops, general superiors, and theological faculties to whom the inquiry was addressed sent 1,998 responses, about which approximately 600 concerned the Mother of God: "500 inquiries expressed a desire for a dogmatic definition [of Mary's mediation], while approximately 400 conveyed the participants' desire for an definition of Her mediation, 50-of Her spiritual motherhood, 50 - of Her co-redemption, and 20-of Her queenship. Approximately 100 respondents, however, did not want any Marian topics to be discussed at the Council at all."14

The results of the inquiry are evident in the eight topics about Mary that the bishops asked to discuss: 1) Mariology in general, 2) spiritual motherhood, 3) perpetual virginity, 4) queenship, 5) the end of Her life on earth (de transito); 6) universal mediation; 7) co-redemption; and 8) no new Marian definitions. ${ }^{15}$ We should take into account that the topics of Mary's spiritual motherhood and co-redemption are intrinsically attached to Her universal mediation. For this reason, since this article concerns John Paul II's reception of the Second Vatican Council's findings, it will focus on Mary's mediation.

In October 1960, the theological commission began preparations for the Second Vatican Council. The commission determined that Marian topics would be addressed in the document on the Church, De Ecclesia. ${ }^{16}$

12 Cf. M. Hauke, Mary, “Mediatress of Grace:” Mary's Universal Mediation of Grace in the Theological and Pastoral Works of Cardinal Mercier (Supplement to Mary at the Foot of the Cross, IV [part B]), New Bedford, MA 2004, pgs. 6-14 (NB: this same work is published in German and in an updated Italian version).

Cf. Hauke, Mercier (2004), pg.125.

Söll (1978) 238. A more detailed explanation (primarily of "Mediation") can be found in: Greco (2011), pgs. 31-56.

15 Cf. Acta et documenta Concilio Vaticano II apparando. Series I (Antepraeparatoria), vol. II, Appendix: Analyticus conspectus consiliorum et votorum quae ab Episcopis et Praelatis data sunt, Civitas Vaticana 1961, pgs. 131-142.

Cf. Besutti (1966) 18; Toniolo (2004), pgs. 21-43. 
Dogmatic Theology

At that time, the subcommittee on the Church prepared a document entitled "On the Church and the Blessed Virgin Mary." In March 1962, the theological commission decided to separate the Marian text from the document on the Church and entitle the former "On the Blessed Virgin Mary, Mother of God and Mother of Mankind." 17 After the Marian schema was presented, a hasty discussion arose on the question of whether the topic of the Mother of God should be presented in its own document or if it should be integrated into the document on the Church. During this debate, two scholarly camps collided. According to Heinrich Maria Köster's proposal from the 1950s, one scholarly trend was called "Christotypical Mariology" and the second trend was called "Ecclesiotypical Mariology." The Christotypical approach to Mary identified the Mother of our Lord more with her Son, so that She was understood vis-à-vis the Church, while the Ecclesiotypical approach emphasized the fact that Mary is a member and the type of the Church. The fact that the Marian schema was integrated into Lumen Gentium could be interpreted as the bishops' decision in favor of the ecclesiotypical approach. The results of the vote that took place on October 29, 1963 were very close: 1114 council fathers voted in favor of integrating the section on Mary into the Dogmatic Constitution on the Church, while 1074 voted in favor of preparing a separate document. ${ }^{18}$ In the end, however, the council fathers came to a kind of compromise: they decided to use a title for the eighth chapter of Lumen Gentium that describes Mary "in the mystery of Christ and of the Church." The council father's wish to consider both scholarly approaches is also evident in the two theologians who were chosen to edit the chapter on Mary: the Croatian Franciscan Carlo Balić, who served as the main editor of the proposed Marian schema and was the President of the international Pontifical Academy of Mary ${ }_{19}^{19}$ and the Belgian theologian Gérard Philips, who served as the primary editor of the entire document of the Dogmatic Constitution on the Church: Lumen Gentium. ${ }^{20}$

17 Cf. Besutti 19-21; Toniolo (2004), pgs. 75.

18 Cf. Besutti 96; Toniolo (2004), pg. 193.

19 Cf. D. Aracić, La dottrina mariologica negli scritti di Carlo Balić, Roma 1980; G. Calvo Moralejo - S. Cecchin (ed.), Memoria eius in benedictione. Atti del simposio internazionale per il primo centenario della nascita di Carlo Balić (1899-1999), Città del Vaticano 2001; Dittrich (2009) 561-565; Greco (2011) 441443; $570 \mathrm{f}$ (Balić's bibliography of Vatican II's Marian publications).

20 Cf. C.M. Antonelli, Le rôle de Mgr Gérard Philips dans la rédaction du chapitre VIII de Lumen gentium, in Marianum 55 (1993), pgs. 17-97; Dittrich (2009) 560f; Greco (2011) 443f; 611f(Philips' bibliography of Vatican II's Marian publications). 
Pope Paul VI determined that Lumen Gentium would discuss the most important doctrines of faith pertaining to Mary in the mystery of Christ and the Church, rather than present a comprehensive doctrine Dogmatic Theology on the Mother of God and seek resolve controversial theological questions on Mary (cf. LG 54). ${ }^{21}$ Therefore, the council fathers focused on two particular questions: 1) Should Mary be called "Mediatrix" and "Mother of the Church"? The majority of the theological commission had already voted not to refer to the two titles explicitly, but to present the doctrine that corresponds to each title..$^{22}$ The proposed text was formulated accordingly: Mary's mediation is presented and understood primarily through Her spiritual motherhood (LG 53, 61f. etc.), while the title "Mediatrix" is only mentioned and the topic is not thematically developed. The document does briefly mention that there is the practice to invoke Mary "under the titles of Advocate, Auxiliatrix, Adjutrix, and Mediatrix" (LG 62) within the Church. The title "Mother of the Church," which the conciliar document discusses without directly stating it, ${ }^{23}$ was solemnly promulgated by Pope Paul VI after the final vote on Lumen Gentium, which took place on November 21, $1964 .{ }^{24}$

The Second Vatican Council aimed to have a "pastoral" character" ${ }^{25}$ and, therefore, did not wish to propose a dogmatic definition of Mary as Mediatrix of all Graces. For this reason, the numerous preparatory votes in favor of a solemn proclamation of Mary's universal mediation of grace were not taken into account. The "pastoral" character of the Second Vatican Council is also evident in the terminology that was (or deliberately not) used in the documents; frequently technical Mariological terms are absent from the texts. In addition, the documents place less focus on Mary because of the Second Vatican Council's ecumenical consideration of Protestantism. For example, titles

21 See the theological commission's declaration that refers to Paul VI's speech delivered on December 4, 1963: Acta Synodalia III/1, 366f.

22 Cf. Besutti 160f; Dittrich (2009) 604; 619; 692.

23 Cf. LG 53: "The Catholic Church, taught by the Holy Spirit, honors her with filial affection and piety as a most beloved mother"; LG 54: "Mary as "Mother of Christ' and 'Mother of men, particularly of the faithful'"; and, LG 61: Mary "is our mother in the order of grace."

24 Cf. Besutti 233; Dittrich (2009), pgs. 690-702.

25 For an extensive explanation of this concept, see: F. Kolfhaus, Pastorale Lehrverkündigung-Grundmotivdes Zweiten Vatikanischen Konzils. Untersuchungen $z u$ "Unitatis Redintegratio," "Dignitatis Humanae" und "Nostra Aetate," Berlin 2010 . 
Dogmatic Theology

such as "Co-Redemptrix" and "Mother of Unity"26 were avoided; in fact, even the title "Mediatrix," which the Eastern Christian Church accepts, was mentioned only very discreetly. The official commentary on the Marian schema for the council noted the following about the title "Co-Redemptrix: "Some expressions and words that have been used by popes and are perfectly correct as such but that separated brethren-especially Protestants-understand with greater difficult have been omitted. Among them is the expression 'Co-Redemptrix of mankind'..." 27 This ecumenical consideration, however, is not entirely consistent: the title "Mother of God," for instance, which the Council of Ephesus solemnly proclaimed, is mentioned without any problem in the documents of Vatican II, ${ }^{28}$ even though Protestants very frequently refute and normally avoid it. ${ }^{29}$

During the Council, Marian topics were addressed in a limited manner, particularly because of pastoral and diplomatic concerns. Nevertheless, from what was discussed, the Second Vatican Council provided a rich doctrine on the Mother of God that had not been presented by any other ecumenical council. The conciliar text on Mary begins with an introduction that emphasizes not only the Incarnation of the Son of God from the Virgin Mary (LG 52), but also Mary's relationship with the Trinity and the Body of Christ, the Church (LG 53). The council "does not, however, have it in mind to give a complete doctrine on Mary, nor does it wish to decide those questions which the work of theologians has not yet fully clarified" (LG 54).

The second subtitle of the Marian chapter is "The Role of the Blessed Mother in the Economy of Salvation" (LG 55-59). This section begins with the Old Testament, which foretells the Mother of the Messiah

$26 \quad$ Cf. A. Apollonio, "Mary Coredemptress: Mother of Unity. A probing glance at the hidden face of Vatican Council II," in AA. VV., Mary at the Foot of the Cross III: Mater Unitatis, New Bedford, Mass. 2004, 316-358; Hauke, Introduzione alla mariologia (2008), pg. 299; Idem, "Maria als 'Mutter der Einheit' (Mater unitatis) als Beitrag zum authentischen interreligiösen Dialog," in "Sedes Sapientiae. Mariologisches Jahrbuch" 15 (2/2011). Pgs. 8-26 (9f); A. Dittrich, "Der Marientitel 'Mater Unitatis' auf dem Zweiten Vatikanum," in M. Hauke (ed.), Maria, "Mutter der Einheit" (Mater unitatis), (Mariologische Studien 28), Regensburg 2020 (in preparation).

27 Acta Synodalia Sacrosancti Concilii Oecumenici Vaticani secundi, vol. I/4, Civitas Vaticana 1971, pg. 99.

28 Mater Dei, Deipara, Dei Genitrix. Cf. LG 53-54, 57, 61, 63, 66 (which refers to the Council of Ephesus), 67, and 69.

29 Cf.A.Dittrich, "Protestantische Mariologie-Kritik. Historische Entwicklung bis 1997 und dogmatische Analyse," Mariologische Studien 11, Regensburg 1998, pgs. 305-307. 
(LG 55). The document goes on to emphasize the Annunciation by the Angel Gabriel and includes the insights of the Fathers of the Church: Mary appears as the New Eve who is associated with the New Adam Dogmatic Theology (Jesus) through Her active cooperation with grace in the salvation of humanity, giving Herself freely through faith and obedience (LG 56). This self-gift is possible because God chose Mary to be Mother of His Divine Son and because of Her singular holiness from the moment of Her conception (LG 56). Mary is presented then in relation to Jesus' infancy (LG 57), to His public activity (LG 58), and after Jesus' Ascension into heaven (LG 59). At the foot of the Cross Mary unites herself with a maternal heart to the sacrifice of her Son and receives a maternal mission to care for the disciple of Jesus (John the Beloved) (LG 58). Assumed body and soul into heaven, She becomes "Queen of the universe," conformed to Christ, "the conqueror of sin and death" (LG 59).

The third subtitle of Lumen Gentium's Chapter VIII describes the relationship between the Blessed Virgin Mary and the Church (LG 60-65). The document first emphasizes Mary's "maternal duty" which "in no wise obscures or diminishes" the "unique mediation of Christ, but rather shows His power" (LG 60). Mary is an "associate" (socia) of the Redeemer; She cooperates in a "singular way [...] in the work of the Savior [...] Wherefore she is our mother in the order of grace" (LG 61). The "maternity of Mary in the order of grace [...] lasts until the eternal fulfillment of all the elect [...] Just as the priesthood of Christ is shared in various ways both by the ministers and by the faithful, and as the one goodness of God is really communicated in different ways to His creatures, so also the unique mediation of the Redeemer does not exclude but rather gives rise to a manifold cooperation which is but a sharing in this one source" (LG 62). Mary is "a type of the Church in the order of faith, charity and perfect union with Christ" (LG 63). Her maternity and virginity are an exemplar of Christian life in spiritual birth by Baptism and in faithful preservation of faith, hope, and charity (LG 63-64). The Church imitates Mary's holiness because the Mother of God "unites in herself and re-echoes the greatest teachings of the faith" (LG 65).

The fourth part of the chapter on Mary discusses the "Cult of the Blessed Virgin in the Church" (LG 66-67). The cult of Mary is "altogether singular" but "differs essentially from the cult of adoration which is offered to the Incarnate Word, as well to the Father and the Holy Spirit" (LG 66). The faithful are encouraged to have a devotion to Mary, "especially the liturgical cult," and to esteem "the practices 
Dogmatic Theology

and exercises of piety, recommended by the magisterium of the Church toward her in the course of centuries." Theologians and preachers should "abstain zealously both from all gross exaggerations as well as from petty narrow-mindedness in considering the singular dignity of the Mother of God" (LG 67).

The fifth subtitle of Chapter VIII describes Mary as "a sign of sure hope and solace to the wandering people of God" (LG 68-69). All Christians, including those separated from the Church, should implore the Mother of God and Mother of men so that "all families of people [...] may be happily gathered together in peace and harmony into one people of God" (LG 69).

\section{The Archbishop of Cracow's Participation in the Conciliar Discussions on Mary}

Karol Wojtyla's Marian teaching is influenced by his homeland's (Poland) intense popular devotion to the Mother of $\operatorname{God}^{30}$ as well as his personal discovery of St. Louis-Marie Grignion de Montfort's Consecration to Mary. ${ }^{31}$ Total consecration to the Mother of God is an existential response to the universal spiritual maternity of Mary; through the consecration, a person accepts Mary's mediation of all graces through Her participation in the universal mediation of Jesus Christ.

In 1656, King Jan Kazimierz consecrated Poland to the Mother of God of Czestochowa as the "Queen of Poland" in thanksgiving for his country's miraculous liberation from the oppression of Protestant

30 Cf. A.B. Calkins, Totus tuus: John Paul II's Program of Marian Consecration and Entrustment, New Bedford/Mass. 1992, pgs. 113-137; Idem, Totus tuus: Pope Saint John Paul II's Program of Marian Consecration and Entrustment, New Bedford/Mass. 2017, pgs. 115-139; J. Schmiedl, "Karol Wojtyla und die marianische Tradition Polens," in A. Ziegenaus (ed.), Totus tuus: Maria in Leben und Lehre Johannes Pauls II. (Mariologische Studien 18), Regensburg 2004, pgs. 11-30; B. Kochaniewicz, La via mariana polacca e la mariologia di Giovanni Paolo II, in T. Siudy (ed.), La Vergine Maria nel magistero di Giovanni Paolo II, Città del Vaticano 2007, pgs. 1-36; Z.S. Jablonski Osppe, Jasna Gora nell'insegnamento e nel ministero di Giovanni Paolo II il Grande, ibidem, pgs. 159-177; L. Ilzo Daniel, La mediazione materna di Maria in Cristo negli insegnamenti di Giovanni Paolo II (Collana di Mariologia 9), Lugano - Gavirate (Varese) 2011, pgs. 3-13.

$31 \quad$ Cf. Calkins (1992), pgs.61-66; (2017), pgs.48-58; A.Ziegenaus, "Die vollkommene Hingabe an Jesus durch Maria nach Ludwig-Maria Grignion von Montfort," in Idem, Totus tuus (2004), pgs. 31-45; G. Riedl, Der Einfluss Louis-Marie Grignions de Montfort (1673-1716) auf die Mariologie Papst Johannes Pauls II, in Ziegenaus, Totus tuus (2004), pgs. 47-69; Ilzo Daniel (2011), pgs. 156-160. 
Sweden. ${ }^{32}$ The Polish Church repeated this consecration with particular fervor and widespread enthusiasm on the part of the people and under the guidance of Cardinal Stefan Wyszynski in 1956. For example, the consecration prayer says: "We ... come to Thy throne, O Mary, Mediatrix of all graces, Mother of mercy and of all consolation.",33 The preservation of the Catholic faith in Poland and the downfall of soviet communism are historically linked to Poland's consecration to the Mother of God.

During the Second Vatican Council, on February 3, 1964, more than 500 bishops asked Pope Paul VI to solemnly consecrate Russia to the Immaculate Heart of Mary in accordance with the message of Fatima. The German and French bishops along with Cardinal Augustine Bea, who was responsible for ecumenism, opposed this request, which was subsequently rejected..$^{34}$ Nevertheless, on November 21,1964 , Pope Paul VI formulated a consecration prayer to Mary in which he included Pope Pius XII's previous consecration to the Immaculate Heart of Mary and announced his visit to Fatima to the bishops who were participating in the council..$^{35}$

The Polish episcopate's requests appear in Cardinal Wyszynski's intervention, which he delivered on September 16, 1964 on behalf of more than 70 Polish bishops, among who was Karol Wojtya.$^{36}$ Wyszynski stressed the pastoral importance of the universal spiritual motherhood of Mary and Her corresponding title as "Mother of the Church," which Paul VI had specifically emphasized at the conclusion of the Second Session of the Second Vatican Council. ${ }^{37}$ The Polish bishops wanted the universal spiritual motherhood of Mary to be more present and evident within the liturgy through the consecration to the Immaculate Heart of Mary. Wyszynski also spoke about the importance

$32 \quad$ Cf. Calkins (1992) 115f; (2017) $117 f$.

33 Consecration at Jasna Gora, August 26, 1956, cited in Calkins (1992), pg. 124; (2017), pg. 127.

$34 \quad$ Cf. R.M. Wiltgen, The Rhine flows into the Tiber, Rockford, IL. 1985, pg. 241; Calkins (1992) 107f; (2017), pg. 109. A hint at Marian consecration, however, can be found in The Decree on the Apostolate of Laity: Apostolicam Actuositatem, 4. LG 67 and cf. Calkins (1992), pg. 108; (2017) 110f also hint at Marian consecration directly and indirectly by referring to forms of piety recommended by the Church throughout the course of history. (2009), pgs. 505-507; Dittrich (2009) 631f; Greco (2011) $180 \mathrm{f}$.

37 Cf. Paul VI, Address given at the conclusion of the second session of Vatican II, December 4, 1963: Acta Synodalia III/1, 441; AAS 56 (1964), pg. 37. 
Dogmatic Theology

of St Louis Grignion de Montfort. Poland's experience demonstrates how greatly the consecration to the Mother of God protects and favors Catholic faith. The Polish bishops believed that placing a greater emphasis on Mary's universal mediation of grace would be a blessing for the entire Church.

The council fathers never had the opportunity to vote on the title "Mother of the Church" because the theological commission blocked this vote. Later, after Lumen Gentium was finished, Pope Paul VI proclaimed Mary as "Mother of the Church." With regard to this issue, the Polish bishops sided with Pope Paul VI and, in 1971, declared the first Monday of Pentecost as the Feast of Mary Mother of the Church. ${ }^{38}$ (In 2018, Pope Francis extended this liturgical memorial to the entire Church of the Roman Rite ${ }^{39}$ ). Even during the conciliar discussions on Mary, Cardinal Wyszynski lamented that bishops did not propose traditional doctrine because of purely ecumenical motives and that expressions that the popes had used (such as "Co-Redemptrix") had been deliberately omitted. ${ }^{40}$

Karol Wojtyla's view on Marian topics is very evident in his written intervention for the $31^{\text {st }}$ General Congregation of the Second Vatican Council on December 1, 1962. The Archbishop of Cracow stresses the necessity to closely connect the Marian schema with the schema on the Church because the Blessed Virgin is Mother of the head and of all of the members of the Mystical Body of Christ. The spiritual maternity of the Church manifests itself especially in Mary as Mediatrix. Mary is Mother of the whole Church, but especially of the afflicted, and of every single human soul. Through Her universal motherhood, people grow in unity with the Body of Christ, the Church. ${ }^{41}$

Cf. Calkins (1992) 132f; (2017), pg. 135.

Cf. Congregation for Worship and the Discipline of the Sacraments, Decree on the Celebration of the Blessed Virgin Mary Mother of the Church in the General Roman Calendar, February 11, 2018, in press.vatican.va (accessed 09.16.2019).

Cf. S. Wyszynski, Acta Synodalia II/3, pg. 683; Antonelli (2009), pg. 251.

Acta Synodalia I/4, 598f: "The schema of De Ecclesia must be closely connected with the schema on the Blessed Virgin Mary. This connection is characterized by the fact that the Blessed Virgin Mary in the Church, the Mystical Body of Christ, is the Mother of the head and also the Mother of all the members and parts of the body. At the same time, the maternity of the Church, presented within the schema more as teacher (teaching community) than as mother, manifests itself. It is necessary, however, that the Church is believed and professed to be the spiritual mother of all souls; this maternity is present especially in the hands and in the heart of the Blessed Virgin and joins itself with the role of mediatrix. For this reason, we think that Mary is the Mother of the whole Church as a community, especially of those members who suffer more, because they need 
This doctrine corresponds perfectly to what we know about Karol Wojtyla's episcopal teaching. ${ }^{42}$

\section{Pope John Paul II's Reception of Conciliar Mariology and How it is Reflected in His Papal Teaching}

Karol Wojtyla guided the Church as the Successor of Peter for 27 years (1978-2005). During his pontificate, he repeatedly cited the texts from Vatican II in his copious teachings on Mary. For example, in his encyclical Redemptoris Mater, he quotes conciliar documents more than 100 times. In addition, the Pope John Paul II also wrote about topics that were neither considered nor fully discussed in the conciliar documents. This is particularly true for Mary's maternal mediation and for the consecration to Her. In his writings, St. Pope John Paul does not simply repeat his predecessors' assertions; instead, he presents his own insights on Marian doctrine that were influenced by his homeland's experience and by the theology of St. Louis-Marie Grignion de Montfort.

\section{The Importance of the Encyclical Redemptoris Mater (1987)}

St. Pope John Paul II's reception of conciliar doctrine is especially evident in the most important magisterial document that he wrote

Her motherly care. Beyond this, we think that she is the mother of every human soul - of every person, and this motherhood is based on Her configuration to Christ, the incarnate Son of God. The same mother wants to bear children similar to her. By the power of the Blessed Virgin's universal maternity, people grow in the unity: her maternity is the basis of the intrinsic unity of the Mystical Body of Christ" (translated from Latin by Manfred Hauke). Cf. Dittrich (2009) 774f. Wojtyla prepared other interventions in the summer 1963 -Acta Synodalia II/3, 856f; cf. Dittrich (2009), 599 - and in September 1964: Acta Synodalia III/2, 178f; cf. Dittrich (2009), pg. 641.

A record of all of Wojtyla's input on Vatican II is published (in Latin with a Spanish translation) in G. Richi Alberti, Karol Wojtyla: un estilo conciliar: las intervenciones de Karol Wojtyla en el Concilio Vaticano II (Studia theologica Matritensia 16), Madrid 2010. The following provide a comprehensive view: J. Grootaers, Karol Wojtyla auf dem zweiten Vaticanum: eine Dokumentation zur Konzilstätigkeit des gegenwärtigen Papstes, in Herder Korrespondenz 33 (1979), pgs. 453-458; Idem, Actes et acteurs à Vatican II, Leuven 1998, pgs. 96-132; Z.J. Kijas (ed.), Cristo Chiesa uomo: il Vaticano II nel pontificato di Giovanni II, Città del Vaticano 2010; G. Marengo, Giovanni Paolo II e il Concilio, Siena 2011.

42 Cf. Ilzo Daniel (2011), pgs. 9-13, refers especially to K. Wojtyla, Maria: Omelie, Città del Vaticano 1980. 
Dogmatic Theology

on the Mother of God: the encyclical Redemptoris Mater (1987). ${ }^{43}$ This doctrinal document is made up of three parts: I. Mary in the Mystery of Christ; II. Mary in the Mystery of the Church; and III. Maternal Mediation (mediatio materna). The first two parts of the encyclical refer to the title of the Marian chapter of Lumen Gentium. ${ }^{44}$ The structure of John Paul II's writing makes it clear that he is emphasizing the maternal mediation of the Mother of God, which is a particularly new approach. John Paul II uses the word "mediation," which the Second Vatican Council strongly de-emphasized for ecumenical reasons, but he qualifies this concept by including the adjective "maternal." In this way, John Paul II does not add anything new (or old) to the doctrine of Vatican II, but rather connects Mary's mediation very closely to the mystery of Christ and the Church. This doctrinal pairing of words is present in the third part of the encyclical where the first subtitle on maternal mediation refers to Jesus Christ, ${ }^{45}$ the second subtitle refers to the Church, ${ }^{46}$ and the third subtitle explains the significance of the Marian year (from Pentecost 1987 to the Assumption [August 15] 1988), for which the document served as an announcement and preparation. ${ }^{47}$

\section{John Paul II's Evaluation of Conciliar Mariology in His Catechesis on Mary (December 13, 1995)}

St. Pope John Paul II's catechesis on Mary (MC), which he gave from 1995-1997, provides an organic magisterial presentation of the whole of Mariology. ${ }^{48}$ In his ninth catechesis, which he delivered at the General Audience on December 13, 1995, John Paul II comments explicitly on

43 Cf., Redemptoris Mater's bibliography (which is also in English), M. Hauke, Die mütterliche Vermittlung, in Ziegenaus, Totus tuus (2004), pgs. 125-175 (but especially pgs. 130-133) (La mediazione materna di Maria secondo Papa Giovanni Paolo II, in Various authors, Maria Corredentrice VIII, Frigento 2005, pgs. 3591); S.M. Perrella, Ecco tua Madre (Gv 19,27). La Madre di Gesù nel magistero di Giovanni Paolo II e nell'oggi della Chiesa e del mondo, Cinisello Balsamo 2007, pgs. 134-166; Ilzo Daniel (2011), pgs. 27-41.

LG, Chapter VIII: "The Blessed Virgin Mary Mother of God, in the mystery of Christ and the Church."

RM 38-41: "Mary, the Handmaid of the Lord."

46

RM 42-47: "Mary in the life of the Church and of every Christian."

RM 48-50.

48

See Hauke, Mütterliche Vermittlung (2004), pgs. 134-146; Perrella, Ecco tua Madre (2007), pgs. 230-276; K. Klauza, I tratti fondamentali della mariologia nelle "Catechesi mariane," in Siudy (2007), pgs. 255-270; Ilzo Daniel (2011), pgs. 51-105. 
the Marian doctrine of Vatican II. He highlights that the Second Vatican Council was "certainly the most important ecclesiastical event" of the $20^{\text {th }}$ century, and that Mary was present in that event in a special Dogmatic Theology way. "In fact, a unique Marian emphasis was typical for the conciliar assembly from the beginning. My venerable predecessor, the Servant of God John XXIII, had already recommended in his Apostolic Letter: Celebrandi Concilii Oecumenici that the faithful ask for the powerful intercession of Mary the 'Mother of Grace and heavenly Patroness of the Council." "49 Then John Paul II recalled the opening of Vatican II, which took place on October 11, 1962, the Feast of the Divine Maternity of the Blessed Virgin Mary. John XXIII chose this date in order to recall Council of Ephesus' proclamation of Mary as the Mother of God (Theotokos). ${ }^{50} \mathrm{He}$ officially announced the Feast of the Divine Maternity of Mary on the feast of the Purification of Mary (February $2,1962)$. In his speech at the opening of the Second Vatical Council, the Pope commended the Council to Mary, "Help of Christians" and "Help of Bishops." ${ }^{51}$ Also the fathers of the council identified with Mary in their message to the world at the beginning of the Conciliar deliberations: "We, the successors of the apostles, are all united in prayer with Mary, the Mother of Jesus, and form a unique apostolic body." 52 So they united themselves "in communion with Mary and with the early Church, which was accompanied by the Holy Spirit" (MC 9.1).

After this introduction, St. Pope John Paul II describes the theological discussion that took place during the Council: "During the second session of the Council, the proposal to include teaching on the Blessed Virgin Mary in the Constitution on the Church was brought forth. The theological commission had explicitly recommended this initiative, but different opinions prevailed." Some thought that this addition was insufficient to stress the very special mission of the Mother of Jesus in the Church. According to this opinion, only a separate document could express the dignity, preeminence, special holiness, and the unique role of Mary in the redemption achieved by Her Son. In some way, those who supported this idea placed Mary above the Church and expressed their concern that inserting Marian doctrine into the treatise on the Church would not sufficiently emphasize the privileges of Mary and would reduce Her role to the level of the other members of the Church (Acta Synodalia II, III, 338-342).

April 11, 1961, AAS 53 (1961), 242.

50 Cf. John XXIII, Motu proprio “Concilium:” AAS 54 (1962), 67-68.

$51 \quad$ Cf. AAS 54 (1962), pgs. 795.

52 Acta Synodalia I/1, pg. 254. 
Others, however, supported the theological commission's proposal to include the doctrinal expositions on Mary and the Church in one document. The theological commission felt that the Council whose aim was to rediscover the People of God's identity and mission should not separate these realities. The proponents of this approach believed that the strict relationship between Mary as the type and model of the Church in Her virginity and maternity and the Church should be presented. As the most excellent member of the ecclesial communion, the Blessed Virgin has a special place in the doctrine on the Church. By stressing the bond between Mary and the Church, the Marian doctrine proposed by the Council would be more easily understood by the Christians of the Reformation (Acta Synodalia II, III, 343-345).

Motivated by the same love for Mary, the council fathers tended to privilege Her diverse traits. Some Fathers contemplated Mary first of all in her relationship to Christ, whereas others emphasized Her membership in the Church" (MC 9.2). John Paul II continues: "After a rich discussion that focused attentively on the dignity of the Mother of God and her special presence in the life of the Church, the decision was made to integrate the Marian treatise into the conciliar document on the Church" (Acta Synodalia II, III, 627).

The new schema on the Blessed Virgin was elaborated on before being integrated into the Dogmatic Constitution on the Church. It also demonstrated real doctrinal progress. The emphasis that it placed on Mary's faith as well as its more systematic approach of basing Marian doctrine on Holy Scripture were important and helpful elements intended to enrich Christians' devotion to and esteem for the Holy Mother of God. Meanwhile, the danger of 'reductionism' that some of the council fathers feared was proven unfounded because they explicitly confirmed the mission and the privileges of Mary; stressed Her cooperation in the divine plan of salvation; and presented the harmonious relationship between Her cooperation and Christ's unique mediation more clearly. For the first time, conciliar teaching had also proposed to magisterially present the role of Mary in the salvific work of Christ and in the life of the Church. Therefore, the council fathers' decision was truly providential and proved to be very fruitful for the successive work of teaching" (MC 9.3).

After affirming the council fathers' work, John Paul II also gently hinted that some of its limits: "During the conciliar sessions, the fathers expressed their desire to further enrich Marian doctrine by affirming Mary's role in the work of salvation. The context in which Mariological debate took place made it impossible for this desire to be fulfilled, 
even if it was widely shared among many of the fathers. However, when taken as a whole, the way in which the Council ultimately presented

Mary is vigorous and balanced, and the very topics that were roughly Dogmatic Theology outlined or addressed before and during Vatican II have since been treated in other Church documents."

The reluctance on the part of these fathers, for instance, did not prevent the Council from using the title "Mediatrix" and establishing among other concepts Mary's mediation from the moment that She consented to be the Mother of God at the Annunciation to Her becoming the Mother of the entire Church in the order of grace until the end of the fulfillment of the elect (cf. LG 62). The Council also highlights Her 'unique' cooperation in restoring supernatural life to souls (LG 61). Moreover, although Lumen Gentium avoids the title "Mother of the Church," it nevertheless clearly stresses the veneration that the Church owes to Mary as the Church's beloved Mother.

When examining the entire eighth chapter of the Dogmatic Constitution on the Church, it is clear that, although the council fathers exercised extreme prudence in the language they chose to write about Mary, this limitation was not an obstacle; the chapter presents a very rich and positive doctrine on Our Lady and is an expression of faith and love for Her who the Church recognizes as it Its mother and exemplar. Moreover, the different opinions that the council fathers expressed during the debates were providential because it spurred them to provide a more complete and balanced presentation of the admirable identity of the Mother of the Lord and of Her extraordinary role in the work of Redemption" (MC 9.4), which, in turn, has enriched the faith and devotion of the people of God.

\section{Examples of Further Development of Conciliar Doctrine}

Since the whole of John Paul II's teaching on Mary is in a certain sense an interpretation of the assertions of the Second Vatican Council, and because it would be impossible to discuss the entire scope of his teachings here (that would require writing a separate book), only a few particularly important points will be noted below.

Mary as the "Spouse of the Holy Spirit"

The Dogmatic Constitution on the Church: Lumen Gentium begins by contemplating the relationship between the Church and the Holy Trinity: Father, Son, and Holy Spirit (LG 2-4) ${ }^{53}$ Likewise, the chapter

53 Cf. Hauke, Die trinitarischen Beziehungen Mariens (2000), pgs. 78-80 (bibliography). 
Dogmatic Theology on Mary begins from a Trinitarian perspective with Mary's divine maternity (LG 52). Mary "is endowed with the high office and dignity of being the Mother of the Son of God, by which she is also the beloved daughter of the Father and the temple of the Holy Spirit" (LG 53). In Her relationship with the Trinity, Mary is the type of the Church and of every Christian, but She is also unique in the way that She is privileged by God. Imitating Mary as Its archetype, the Church is "Mother" by receiving the Word of God through faith, preaching, and Baptism, as the Council explains (LG 63f). Only Mary, however, is called by the title "Mother of God." Mary's uniqueness, however, is not manifested in Her relationship to the Holy Spirit: for, the conciliar document calls Mary a "temple" (sacrarium) of the Holy Spirit and, thus, uses an expression that it applies to every Christian. The main editor of Lumen Gentium, Gérard Philips notes that the word "temple" does not distinguish between divine maternity and sanctifying grace, even though the liturgy knows this expression. ${ }^{54}$

One conciliar father's desire to substitute the word "temple" with "spouse" was not accepted. ${ }^{55}$ Nevertheless, the Marian title "Spouse of the Holy Spirit" has been used since the time of St. Francis. ${ }^{56}$ The reason why the request was refused (which is not recorded in Acta Synodalia) is due, perhaps, to the fact that the corresponding title "Bridegroom" is used for the Holy Spirit, which could create the misunderstanding that the Holy Spirit is the Father of Jesus. ${ }^{57}$ In $\mathrm{Lu}$ men Gentium, the Church is the "Spouse" of Christ and Christ is the "Bridegroom" (LG 4), so the use of this expression could depend on the specific context of the Dogmatic Constitution on the Church..$^{58}$

In his writings, John Paul II uses the expression "Spouse of the Holy Spirit," which the Council had avoided, and gives the following plausible explanation for doing so during his catechesis on Mary: every Christian is a "temple of the Holy Spirit" (1Cor 6:19), but in Mary "this relationship to the Holy Spirit is enriched by the spousal

$54 \quad$ Cf. Philips (1993), pg. 526.

55 Cf. Acta Synodalia III/2, pgs. 124-126 (Grotti); Hauke (2000) 99f.

Cf. J. Schneider, Virgo Ecclesia Facta: Die Gegenwart Marias auf dem Kreuzbild von San Damiano und im "Officium Passionis" des Heiligen Franziskus von Assisi, St. Ottilien 1998 (Part II, Chapter III); E. Richer, "Marie, Epouse du Saint-Esprit? Le point de vue de la mariologie des saints et des papes," in Rivista teologica di Lugano 12 (2007), pgs. 257-277 (265); L. Bonarrigo, Maria Sposa dello Spirito Santo nella teologia contemporanea (Collana di Mariologia 15), Lugano-Siena 2018, pgs. 163-176.

K. Wittkemper, Braut, in Marienlexikon 1 (1988), pgs. 564-571 (569f).

Cf. Hauke (2000), pg. 111; Bonarrigo (2018), pgs. 273-306. 
dimension. I have recalled this in the encyclical Redemptoris Mater: 'The Holy Spirit had already come down upon her, and she became his faithful spouse at the Annunciation, welcoming the Word of the true Dogmatic Theology God ..."' (MC 11.4, January 10, 1996, with reference to RM 26)..$^{59}$ The Belgian Jesuit Jean Galot, ${ }^{60}$ who taught Christology and Mariology at the Pontifical Gregorian University for many years, emphasized the same idea; John Paul II's catechesis on Mary contains many parallels to Galot's Mariological works. ${ }^{61}$ In this way, Pope John Paul II offers a balanced and broader view that presents Mary's personal relationship to the Holy Spirit, rather than a narrow view that portrays Her only as His "temple."

\section{Mary at the Foot of the Cross}

Another example of how John Paul II elaborated on the doctrine of Vatican II is his papal coat of arms, which refers to the Mary's salvific cooperation in Redemption through Her presence at the foot of the Cross and Her spiritual maternity towards the beloved disciple (St. John) who represents all those who follow Christ. Lumen Gentium states: the Blessed Virgin "faithfully persevered in her union with her Son unto the cross, where she stood, in keeping with the divine plan (cf. John 19:25), grieving exceedingly with her only begotten Son, uniting herself with a maternal heart with His sacrifice, and lovingly consenting to the immolation of this Victim which she herself had brought forth. Finally, she was given by the same Christ Jesus dying on the cross as a mother to His disciple with these words: 'Woman, behold thy son' (cf. John 19:26-27)" (LG 58).

The interpretation of Mary as the spiritual mother of Christ's disciples and (implicitly) as "Mother of the Church" has existed since the $12^{\text {th }}$ century, ${ }^{62}$ even though the Gospel of John itself already implies this reality. Many biblical scholars have studied this topic; in fact, when Vatican II took place, particular academic circles were familiar with various works on it, and even Protestant studies had been conducted

59 See various other texts such as Pope John Paul II's homily on December 8, 1982 (which refers to St. Maximilian Kolbe); and address given at the General Audiences on June 28, 1989 and May 2, 1990: see Richer (2007) 263f; Bonarrigo (2018), pgs. 406-420. IV 13-25 (18-20). 
Dogmatic Theology

in this area. ${ }^{63}$ Moreover, the basis for Catholic Mariology is not only exegesis on the literal sense, but also how Mariology is understood and conveyed in a deeper way in the Tradition of the Church.

In the draft of the conciliar document, the beloved disciple was called a "symbol of the faithful" (fidelium figura) who are entrusted to the maternal care of Mary. ${ }^{64}$ This description corresponds well with the Tradition of the Church and to the teaching of the popes who served before Vatican II. ${ }^{65}$ During the Second Vatican Council, however, the expression "symbol of the faithful" was rejected by the Theological Commission because the President of the Pontifical Council for Promoting Christian Unity-the German Cardinal Augustine Bea-objected to it. Bea argued that Protestant biblical scholars in particular had not yet come to such a "symbolic" interpretation of the beloved disciple entrusted to the Mother of Jesus."66

John Paul II, however, especially in Redemptoris Mater, exposes the profound significance of Jesus' "words spoken from the Cross." ${ }^{67} \mathrm{He}$ says, "Mary's motherhood of the human race [...] emerges from the definitive accomplishment of the Redeemer's Paschal Mystery. The Mother of Christ, who stands at the very center of this mystery-a mystery which embraces each individual and all humanity-is given as mother to every single individual and all mankind." 68

63 Cf. Laurentin, Vierge au Concile, pgs. 107-109; Hauke, Introduzione alla mariologia (2008), pgs. 65-74 (bibliography); A. Serra, Maria presso la Croce, Padova 2011.

$64 \quad$ Cf. Acta Synodalia III, 1, pg. 357.

65 Cf. J.M. Salgado, La Maternité spirituelle de la Très Sainte Vierge Marie (Studi Tomistici 36), Città del Vaticano 1990, pgs. 154-159 (all popes since Benedict XIV).

66 Cf.Acta Synodalia III, 1, pg. 455; S.M. Perrella, Maria, Madre di Gesù nel servizio al compimento del Regno. Una questione attuale, in E. Perretto (Hrsg.), Maria nel mistero di Cristo pienezza del Regno, Roma 1999, pgs. 537-618 (586f); Ilzo Daniel (2011) 135f. On the Marian attitudes of Bea see also Dittrich (2009) 559f; Greco (2011) 184f.

67 For John Paul II's interpretation of John 19:25-27 see L. Diez Merino, "María junto a la Cruz (Jn 19,25-27). Relectura evangélica de Juan Pablo II en la Redemptoris Mater," in Marianum 50 (1988), pgs. 366-396; J.M. Phan Nam, The biblical sources of Pope John Paul's teaching on Mary's maternal mediation, Roma 1995; A.M. Serra, "Documenti biblici e acquisizioni esegetiche nei documenti di Giovanni Paolo II," in Toniolo, Il magistero mariano di Giovanni Paolo II (2006), pgs.109-134; Ilzo Daniel (2011), pgs. 128-139.

$68 \quad$ RM 23; cf. RM 44; Pope John Paul II's address given at the general audience on November 23, 1988 (Insegnamenti di Giovanni Paolo II, vol. XI,4, Città del Vaticano 1991, pgs. 1634-38); MC 49, April 23, 1997; Ilzo Daniel (2011), pgs. 128-140. 
Here St. Pope John Paul II closes the spiritual gap left by the Council, which had been influenced by an exaggerated consideration of Protestantism. The same is true for the teaching on Mary's relationDogmatic Theology ship to Christ's sacrifice on the Cross. In this instance, a footnote in Lumen Gentium refers to Pope Pius XII's encyclical Mystici Corporis Christi, which goes beyond the Conciliar affirmation and states that Mary was not only profoundly united with her Son, but that She also offered Him to the eternal Father on Calvary. ${ }^{69}$ In his Apostolic Letter Marialis Cultus (1974), Pope Paul VI had emphasized this aspect. ${ }^{70}$ John Paul II understood that the passage cited in the conciliar document hinted at "a genuine act of love by which she offers her Son as a 'victim' of expiation for the sins of all humanity." made the same observation when commenting on Paul VI's Marialis Cultus: it not only expresses Mary's compassion for her Son, "but also her cooperation in her Son's sacrifice."72

\section{Technical Terms: "Co-Redemptrix" and "Mediatrix of all Graces"}

Pope John Paul II's decision to present a complete doctrine on Mary is also manifested in his use of the expression "Co-Redemptrix," which—as stated previously—the conciliar commission avoided during its deliberations for ecumenical reasons, even though the expression was perfectly correct from a theological point of view. The expression "Co-Redemptrix" signifies Mary's unique cooperation in the work of Redemption, ${ }^{73}$ which Vatican II also taught. ${ }^{74}$ When the Church avoids

$69 \quad$ Pius XII, Mystici Corporis (1943): AAS 35 (1943), 247: “It was She (Mary) who, immune from all sin, personal or inherited, and ever most closely united with her Son, offered him on Golgotha to the eternal Father together with the holocaust of her maternal rights and motherly love, like a New Eve, for all the children of Adam contaminated through this unhappy fall..." (English translation in Our Lady: Papal Teachings, Boston 1961, pg. 383).

$71 \quad$ MC 47.2, April 2, 1997 (English translation can be found in M. Miravalle, "With Jesus:" The Story of Mary Co-Redemptrix, Goleta, CA 2003, pg. 205). Cf. the comment in Hauke, Mütterliche Vermittlung, $137 f$ (referring, among other texts, to the Encyclical Evangelium Vitae, 1995, no. 103).

72 L. Scheffczyk, Neue Impulse zur Marienverehrung, St. Ottilien 1974, pg. 37.

73 Cf. Hauke, Mercier (2004), pgs. 60-66.

74 Cf. M. Hauke, "Die Lehre von der 'Miterlöserin' im geschichtlichen Durchblick," in Sedes Sapientiae. Mariologisches Jahrbuch 11 (1/2007) 17-64 (53-57); see Idem, "Die aktive Mitwirkung Mariens an der Erlösung. Ein geschichtlicher Durchblick," in A. Graf von Brandenstein-Zeppelin - A. von Stockhausen - J.H. Benirschke (eds.), Die göttliche Vernunft und die inkarnierte Liebe. Festschrift zum 80. Geburtstag Seiner Heiligkeit Papst Benedikts XVI, Weilheim-Bierbronnen 
Dogmatic Theology

using certain terms, however, She risks weakening the faithful's awareness of the truths that these expressions convey.

By referring to Mary's sacrifice on Golgotha, John Paul II brings to bear the footnote of the Council that cites Pope Pius XII's aforementioned assertion. John Paul II also uses the expressions "CoRedemptrix" and "co-redemption" multiple times. ${ }^{75}$ He does the same with the technical description of Mary "Mediatrix of all Graces." This expression does not appear in Lumen Gentium, but it does show up in the magisterial documents that are cited in the footnotes of the Dogmatic Constitution on the Church. ${ }^{76} \mathrm{John}$ Paul II describes Mary's universal mediation of grace by referring to her "maternal" mediation in Christ. This formulation averts the possible erroneous interpretation that Mary merited in Christ even the graces bestowed on Her. ${ }^{77}$ Such an understanding would be incorrect: for, Mary depends on the superabundant merit of the Redeemer for and in everything. In this way, She cannot cooperate in Her own Redemption, but She can cooperate as the New Eve in the spiritual birth of the other members of

2007, pgs. 13-48; Idem, "La cooperazione attiva di Maria alla Redenzione. Prospettiva storica (patristica, medievale, moderna, contemporanea)," in Telesphore Cardinale Toppo et al. (eds.), Maria, "unica cooperatrice alla Redenzione." Atti del Simposio sul Mistero della Corredenzione Mariana, Fatima, Portogallo, 3-7 Maggio 2005, New Bedford, MA 2005, pgs. 171-219; = Immaculata Mediatrix 6 (2/2006) 157-189; = Coredemptrix. Annali Mariani 2007, Frigento 2008, pgs. 45-88.

A.B. Calkins, "Pope John Paul II's Ordinary Magisterium on Marian Coredemption: Consistent Teaching and More Recent Perspectives," in Various authors, Mary at the Foot of the Cross, II, New Bedford, MA 2002, pgs. 1-36; = Divinitas 45 (2002), pgs. 153-185; (2017), pgs. 352-354; Miravalle, With Jesus (2003), pgs 189-212. Ilzo Daniel (2011), pgs. 116-118. The sources are John Paul II, General Audience, December 1980; General Audience, September 8, 1982; Angelus on the Feast of St. Charles Borromeo, Arona, November 4, 1984; Angelus, March 31, 1985; Address at the Marian Shrine of Guayaquil, Ecuador, January 31, 1987; Speech to the Volunteers of Lourdes, March 24, 1990; Angelus on the Jubilee of Saint Bridget of Sweden, October 6, 1991.

On LG 62 see P.M. Siano, "Uno studio su Maria Santissima 'Mediatrice di tutte le grazie' nel magistero pontificio fino al pontificato di Giovanni Paolo II," in Immaculata Mediatrix 6 (2006), pgs. 299-355 (321-327); reprinted in Autori vari (Various authors), Maria Corredentrice. Storia e teologia VIII, Frigento 2006, pgs. 191-266 (224-228); M. Hauke, "Maria als mütterliche Mittlerin in Christus. Ein systematischer Durchblick," in Sedes Sapientiae. Mariologisches Jahrbuch 12 (2/2008), pgs. 13-53 (53); In English as: "Mary's Motherly Mediation in Christ: A Systematic Reflection," in Nova et Vetera, English edition 7 (4/2009), pgs. 941972 (972). This is true especially for the Leo XIII's Adiutricem Populi and Pius X's Ad Diem Illum.

77 Cf. Hauke, Mütterliche Vermittlung (2004), pg. 173; Idem, Mercier (2004), pg. 12; Idem, Mary's Motherly Mediation (2009), $970 \mathrm{f}$. 
the Mystical Body of Christ. This is evident in John Paul II's use of the expression "maternal" mediation" which is clearly distinct from participation in Christ's mediation through Holy Orders. ${ }^{78}$ Several times, John Paul II even writes the expression "Mediatrix of all Graces," which was included in the liturgy of the Holy Mass for the Feast of the Mediatrix of all Graces that Benedict XV permitted the bishops of Belgium to celebrate in 1921 and which was later celebrated throughout the world in numerous dioceses and religious orders. ${ }^{80}$ That liturgy is part of the Roman Missal of 1962 and celebrated "pro aliquibus locis" ("for some places," i.e., on May $8^{\text {th }}$ ) in the Extraordinary Form of the Roman Rite. Frank Duff, the Founder of the Legionaries of Mary, also incorporated the title "Mediatrix" into the "Catena Legionis," which every Legionary throughout the world still prays:

O Lord Jesus Christ, our Mediator with the Father, who hast been pleased to appoint the Most Blessed Virgin, Thy Mother, to be our Mother also, and our Mediatrix with Thee, mercifully grant that whosoever comes to Thee seeking Thy favours, may rejoice to receive all of them through her. Amen.

Since the Eastern Church has used title "Mediatrix" in its Tradition for centuries, John Paul II refers to this fact during one of his Angelus addresses during the Marian Year of 1988. Specifically, the Pope mentions the Coptic sanctuary that was built in the fifth century and is located in what is now the Maadi district of Cairo: "Many pilgrims continually come to this sanctuary to present their petitions to the Mediatrix of all graces." 81

\section{A Paradigm for Interpreting the Second Vatican Council}

Many other examples of how the Marian teachings of Vatican II are reflected in St. Pope John Paul II's writings exist. In the end, however, his Marian encyclical Redemptoris Mater and his catechesis on Mary

78 John Paul II develops this distinction especially in his Apostolic Letter: Mulieris Dignitatem (1988), nn. 25-27; cf. Hauke, Mütterliche Vermittlung (2004), pgs. 158-161.

79 Cf. Hauke, Mütterliche Vermittlung (2004), pgs. 170-173; Siano (2006), pgs. 342345 (Immaculata Mediatrix); pgs. 249-253 (Maria Corredentrice VIII); A.M. Apollonio, "Mary Mediatrix of All Graces," in M.I. Miravalle (ed.), Mariology, Goleta, CA 2007, pgs. 411-465 (458-460).

80 Cf. Hauke, Mercier (2004), pgs. 54-60; A.B. Calkins, "Mary Co-Redemptrix: The Beloved Associate of Christ," in M.I. Miravalle (ed.), Mariology, Goleta, CA 2007, pgs. 349-409 (388-391).

81 John Paul II, Insegnamenti ... XI/1, 119. 
Dogmatic Theology

are (in addition to the eighth chapter of Lumen Gentium) the most comprehensive magisterial expositions on Catholic Mariology. John Paul II traces the conciliar teaching back to the great river of Holy Tradition and also introduces emphasizes other aspects based in great measure on the spirituality of St. Louis-Marie Grignion de Montfort. John Paul II synthesizes in an original and harmonious way both old and new (nova et vetera) Marian teachings. The Polish pope joins the Christotypical camp of theology by writing about Mary's mediation and Her role as the type and Mother of the Church. The universal maternal mediation of Mary in Christ is reflected in what is the pinnacle of Marian devotion-namely, consecration to the Mother of God. While the conciliar documents do not speak about this consecration, they do refer to the interior dynamics of the spiritual maternity of Mary, which consequently leads us - the faithful—to offer ourselves entirely to Mary in order to imitate to Christ in the most intense way. From this perspective, John Paul II is an excellent leader in correctly interpreting Vatican II.

\section{Bibliography:}

1. A.M. Serra, "Documenti biblici e acquisizioni esegetiche nei documenti di Giovanni Paolo II," in Toniolo, Il magistero mariano di Giovanni Paolo II (2006), pgs. 109-134.

2. Anton A., El misterio de la Iglesia. Evolución historica de las ideas eclesiologicas II, Madrid-Toledo 1987.

3. Antonelli C., Il dibattito su Maria nel Concilio Vaticano II. Percorso redazionale sulla base di nuovi documenti di archivio, Padova 2009.

4. Antonelli C.M., Le rôle de Mgr Gérard Philips dans la rédaction du chapitre VIII de Lumen gentium, in Marianum 55 (1993), pgs. 17-97.

5. Apollonio A., "Mary Coredemptress: Mother of Unity. A probing glance at the hidden face of Vatican Council II," in AA. VV., Mary at the Foot of the Cross III: Mater Unitatis, New Bedford, Mass. 2004, 316-358.

6. Apollonio A.M., "Mary Mediatrix of All Graces," in M.I. Miravalle (ed.), Mariology, Goleta, CA 2007, pgs. 411-465.

7. Aracić D., La dottrina mariologica negli scritti di Carlo Balić, Roma 1980.

8. Balić C., "El capitolo VIII de la constitución 'Lumen gentium' comparado con el primer esquema de la Virgen Madre de la Iglesia," in Estudios Marianos 27 (1966), pgs. 135-183.

9. Baraúna G. (ed.), "De Ecclesia,” Beiträge zur Konstitution „Über die Kirche"des Zweiten Vatikanischen Konzils, 2 vols., Frankfurt 1966 (French edition: L'Eglise de Vatican II, 3 vols., Paris 1966-67).

10. Besutti G., Lo schema mariano del Vaticano II. Documentazione e note di cronaca, Roma 1966.

11. Bonarrigo L., Maria Sposa dello Spirito Santo nella teologia contemporanea (Collana di Mariologia 15), Lugano-Siena 2018, pgs. 163-176. 
12. Calkins A.B., Introduzione, in A.B. Calkins (ed.), Giovanni Paolo II, Totus tuus. Il magistero mariano di Giovanni Paolo II, Siena 2006, pgs. 9-37.

13. Calkins A.B., Totus tuus: John Paul II's Program of Marian Consecration and Entrustment, New Bedford/Mass. 1992, pgs. 113-137.

14. Calkins A.B., Totus tuus: Pope Saint John Paul II's Program of Marian Consecration and Entrustment, New Bedford/Mass. 2017, pgs. 115-139.

15. Calkins A.B., "Mary Co-Redemptrix: The Beloved Associate of Christ," in M.I. Miravalle (ed.), Mariology, Goleta, CA 2007, pgs. 349-409.

16. Calkins A.B., "Pope John Paul II's Ordinary Magisterium on Marian Coredemption: Consistent Teaching and More Recent Perspectives," in Various authors, Mary at the Foot of the Cross, II, New Bedford, MA 2002, pgs. 1-36.

17. Calvo Moralejo G., Cecchin S. (ed.), Memoria eius in benedictione. Atti del simposio internazionale per il primo centenario della nascita di Carlo Balić (1899-1999), Città del Vaticano 2001.

18. Congregation for Worship and the Discipline of the Sacraments, Decree on the Celebration of the Blessed Virgin Mary Mother of the Church in the General Roman Calendar, February 11, 2018, in press.vatican.va (accessed 09.16.2019).

19. Cyril of Alexandria, Sermo 4 (PG 77, 992-996) (Sermon at the Council of Ephesus).

20. De Fiores S., Concilio Vaticano II, in S. De Fiores, Maria. Nuovissimo Dizionario I, Bologna 2006, 323-358.

21. Diez Merino L., "María junto a la Cruz (Jn 19,25-27). Relectura evangélica de Juan Pablo II en la Redemptoris Mater," in Marianum 50 (1988), pgs. 366-396.

22. Dittrich A., Mater Ecclesiae. Geschichte und Bedeutung eines umstrittenen Marientitels, Würzburg 2009, pgs. 573-686.

23. Dittrich A., "Der Marientitel 'Mater Unitatis' auf dem Zweiten Vatikanum," in M. Hauke (ed.), Maria, "Mutter der Einheit" (Mater unitatis), (Mariologische Studien 28), Regensburg 2020 (in preparation).

24. Dittrich A., "Protestantische Mariologie-Kritik. Historische Entwicklung bis 1997 und dogmatische Analyse," Mariologische Studien 11, Regensburg 1998.

25. Galot J., La mediazione di Maria: natura e limiti, in La Civiltà Cattolica 1997, IV 13-25.

26. Greco A., "Madre dei viventi." La cooperazione salvifica di Maria nella "Lumen gentium:" una sfida per oggi (Collana di Mariologia 10), LuganoGavirate (Varese) 2011.

27. Grootaers J., Actes et acteurs à Vatican II, Leuven 1998, pgs. 96-132.

28. Grootaers J., Karol Wojtyla auf dem zweiten Vaticanum: eine Dokumentation zur Konzilstätigkeit des gegenwärtigen Papstes, in Herder Korrespondenz 33 (1979).

29. Hauke M., Die marianischen Aussagen des Zweiten Vatikanischen Konzils und ihre Interpretation durch Johannes Paul II, in Sedes Sapientiae. Marianisches Jahrbuch 16 (1/2012), pgs. 58-88. 
Dogmatic Theology
30. Hauke M., Die mütterliche Vermittlung, in A. Ziegenaus, Totus tuus (2004), pgs. 125-175.

31. Hauke M., Die trinitarischen Beziehungen Mariens als Urbild der Kirche auf dem Zweiten Vatikanischen Konzil, in Sedes Sapientiae. Mariologisches Jahrbuch 4 (2/2000), pgs. 78-114.

32. Hauke M., Introduzione alla mariologia (Collana di Mariologia 2), LuganoVarese 2008, pgs. 94-98 (Introduction to Mariology, Washington, DC 2019 - manuscript in preparation).

33. Hauke M., Mary, "Mediatress of Grace:” Mary's Universal Mediation of Grace in the Theological and Pastoral Works of Cardinal Mercier (Supplement to Mary at the Foot of the Cross, IV [part B]), New Bedford, MA 2004, pgs. 6-14.

34. Hauke M., Totus tuus. Theologische Grundlagen der Marienweihe, in A. von Brandenstein-Zeppelin etc. (eds.), Im Dienste der inkarnierten Wahrheit. Festschrift zum 25jährigen Pontifikat Seiner Heiligkeit Papst Johannes Pauls II, Weilheim-Bierbronnen 2003, pgs. 127-148 (127-130).

35. Hauke M., "Die aktive Mitwirkung Mariens an der Erlösung. Ein geschichtlicher Durchblick," in A. Graf von Brandenstein-Zeppelin, A. von Stockhausen, J.H. Benirschke (eds.), Die göttliche Vernunft und die inkarnierte Liebe. Festschrift zum 80. Geburtstag Seiner Heiligkeit Papst Benedikts XVI, Weilheim-Bierbronnen 2007, pgs. 13-48.

36. Hauke M., "Die Lehre von der 'Miterlöserin' im geschichtlichen Durchblick," in Sedes Sapientiae. Mariologisches Jahrbuch 11 (1/2007) 17-64.

37. Hauke M., "La cooperazione attiva di Maria alla Redenzione. Prospettiva storica (patristica, medievale, moderna, contemporanea)," in Telesphore Cardinale Toppo et al. (eds.), Maria, "unica cooperatrice alla Redenzione." Atti del Simposio sul Mistero della Corredenzione Mariana, Fatima, Portogallo, 3-7 Maggio 2005, New Bedford, MA 2005, pgs. 171-219.

38. Hauke M., "Maria als mütterliche Mittlerin in Christus. Ein systematischer Durchblick," in Sedes Sapientiae. Mariologisches Jahrbuch 12 (2/2008), pgs. 13-53.

39. Hauke M., "Maria als 'Mutter der Einheit' (Mater unitatis) als Beitrag zum authentischen interreligiösen Dialog," in "Sedes Sapientiae. Mariologisches Jahrbuch" 15 (2/2011). Pgs. 8-26.

40. Hauke M., "Mary's Motherly Mediation in Christ: A Systematic Reflection," in Nova et Vetera, English edition 7 (4/2009), pgs. 941-972.

41. Hünermann P., Theologischer Kommentar zur dogmatischen Konstitution über die Kirche Lumen gentium, in P. Hünermann, B.J. Hilberath (eds.), Herders Theologischer Kommentar zum Zweiten Vatikanischen Konzil II, Freiburg i.Br. 2004, pgs. 263-563.

42. Ilzo Daniel L., La mediazione materna di Maria in Cristo negli insegnamenti di Giovanni Paolo II (Collana di Mariologia 9), Lugano - Gavirate (Varese) 2011, pgs. 3-13.

43. Jablonski Z.S., Jasna Gora nell'insegnamento e nel ministero di Giovanni Paolo II il Grande, in T. Siudy (ed.), La Vergine Maria nel magistero di Giovanni Paolo II, Città del Vaticano 2007, pgs. 159-177.

44. John Paul II, Mulieris Dignitatem (1988). 
45. Kijas Z.J. (ed.), Cristo Chiesa uomo: il Vaticano II nel pontificato di Giovanni II, Città del Vaticano 2010.

46. Kochaniewicz B., La via mariana polacca e la mariologia di Giovanni Paolo Dogmatic II, in T. Siudy (ed.), La Vergine Maria nel magistero di Giovanni Paolo II, Città del Vaticano 2007, pgs. 1-36.

47. Kolfhaus F., Pastorale Lehrverkündigung - Grundmotiv des Zweiten Vatikanischen Konzils. Untersuchungen zu "Unitatis Redintegratio," "Dignitatis Humanae" und "Nostra Aetate," Berlin 2010.

48. Laurentin R., La Madonna del Vaticano II, Bergamo 1965 (French original: La Vierge au Concile, Paris 1965).

49. Leo XIII Adiutricem Populi.

50. Marengo G., Giovanni Paolo II e il Concilio, Siena 2011.

51. Miravalle M., "With Jesus:” The Story of Mary Co-Redemptrix, Goleta, CA 2003.

52. Our Lady: Papal Teachings, Boston 1961.

53. O'Carroll M., "Theotokos," A Theological Encyclopedia of the Blessed Virgin Mary, Eugene, OR ${ }^{2} 2000$, pgs. 351-356 (with more titles in English).

54. Paul VI, Address given at the conclusion of the second session of Vatican II, December 4, 1963: Acta Synodalia III/1, 441.

55. Perrella S.M., Concilio Vaticano II, in S. de Fiores etc. (eds.), Mariologia, Cinisello Balsamo 2009, 308-319.

56. Perrella S.M., Ecco tua Madre (Gv 19,27). La Madre di Gesù nel magistero di Giovanni Paolo II e nell'oggi della Chiesa e del mondo, Cinisello Balsamo 2007, pgs. 134-166.

57. Perrella S.M., I "vota" e $i$ "consilia" dei vescovi italiani sulla mariologia e sulla corredenzione nella fasi antipreparatoria del Concilio Vaticano II, Roma 1994.

58. Perrella S.M., La Madre di Gesù nella coscienza ecclesiale contemporanea, Città del Vaticano 2005, pgs. 1-140.

59. Perrella S.M., Maria, Madre di Gesù nel servizio al compimento del Regno. Una questione attuale, in E. Perretto (Hrsg.), Maria nel mistero di Cristo pienezza del Regno, Roma 1999, pgs. 537-618.

60. Phan Nam J.M., The biblical sources of Pope John Paul's teaching on Mary's maternal mediation, Roma 1995.

61. Philips G., La Chiesa e il suo mistero nel Concilio Vaticano II. Storia, testo e commento della Costituzione "Lumen gentium," Milano 1975 (French original reprinted in 1993: L'Église et son mystère, Paris 1967).

62. Pius X Ad Diem Illum.

63. Pius XII, Mystici Corporis (1943): AAS 35 (1943).

64. Rahner K., Das neue Bild der Kirche, in Geist und Leben 39 (1966) 4-24.

65. Ratzinger J., The Ratzinger Report, San Francisco 1985.

66. Richer E., "Marie, Epouse du Saint-Esprit? Le point de vue de la mariologie des saints et des papes," in Rivista teologica di Lugano 12 (2007), pgs. 257-277.

67. Richi Alberti G., Karol Wojtyla: un estilo conciliar: las intervenciones de Karol Wojtyla en el Concilio Vaticano II (Studia theologica Matritensia 16), Madrid 2010. 
Dogmatic Theology

68. Riedl G., Der Einfluss Louis-Marie Grignions de Montfort (1673-1716) auf die Mariologie Papst Johannes Pauls II, in A. Ziegenaus, Totus tuus (2004), pgs. 47-69.

69. Salgado J.M., La Maternité spirituelle de la Très Sainte Vierge Marie (Studi Tomistici 36), Città del Vaticano 1990, pgs. 154-159.

70. Schatz K., Vaticanum I 1869-1870, vol. II, Paderborn 1993.

71. Scheffczyk L., Neue Impulse zur Marienverehrung, St. Ottilien 1974.

72. Scheffczyk L., Vaticanum II, in Marienlexikon 6 (1994), pgs. 567-571.

73. Schmiedl J., "Karol Wojtyla und die marianische Tradition Polens," in A. Ziegenaus (ed.), Totus tuus: Maria in Leben und Lehre Johannes Pauls II. (Mariologische Studien 18), Regensburg 2004, pgs. 11-30.

74. Schneider J., Virgo Ecclesia Facta: Die Gegenwart Marias auf dem Kreuzbild von San Damiano und im "Officium Passionis" des Heiligen Franziskus von Assisi, St. Ottilien 1998.

75. Serra A., Maria presso la Croce, Padova 2011.

76. Siano P.M., "Uno studio su Maria Santissima 'Mediatrice di tutte le grazie' nel magistero pontificio fino al pontificato di Giovanni Paolo II," in Immaculata Mediatrix 6 (2006), pgs. 299-355.

77. Söll G., Mariologie (HDG III,4), Freiburg i.Br. 1978, 238-240.

78. Toniolo E.M. (ed.), Maria nel Concilio. Approfondimenti e percorsi a 40 anni dalla "Lumen gentium," Roma 2005.

79. Toniolo E.M., La Beata Vergine Maria nel Concilio Vaticano II. Cronistoria del capitolo VII della Costituzione dogmatica "Lumen gentium" e sinossi di tutte le redazioni, Roma 2004.

80. Wiltgen R.M., The Rhine flows into the Tiber, Rockford, IL. 1985.

81. Wittkemper K., Braut, in Marienlexikon 1 (1988), pgs. 564-571.

82. Wojtyla K., Maria: Omelie, Città del Vaticano 1980.

83. Ziegenaus A., "Die vollkommene Hingabe an Jesus durch Maria nach Ludwig-Maria Grignion von Montfort," in A. Ziegenaus, Totus tuus (2004), pgs. 31-45. 